\title{
Synopsis of Poaceae in the grassland formations of the Parque Estadual do Guartelá, Paraná State, Brazil ${ }^{1}$
}

\author{
(1) Tainã de Souza ${ }^{2,4}$, Rafael Trevisan ${ }^{3}$ and Shirley Martins Silva ${ }^{2}$
}

Received: 20.06.2017; accepted: 12.03.2018

\begin{abstract}
Synopsis of Poaceae in the grassland formations of the Parque Estadual do Guartelá, Paraná State, Brazil). Poaceae is a cosmopolitan family that includes species found in both forest and grassland formations. The objective of this study was to carry out the first floristic survey of Poaceae in the Parque Estadual do Guartelá (PEG), one of the last remnants of native grassland vegetation in the State of Paraná, Brazil, and provide resources to assist the identification of genera and species. The survey was conducted based on field collections and searches in the Species Link online database. In the PEG, Poaceae is represented by 29 genera and 54 species, being Paspalum L. (eight spp.), Andropogon L. (five spp.) and Eragrostis Wolf (four spp.) the richest genera. The number of species in the PEG was incremented by 29 new records. In addition, five species were classified as exotic, five as endemic to Brazil, and two were considered least concern in relation to their conservation. We also present information regarding the distribution, habitat and conservation status for each species. Keywords: Campos Gerais, floristic, Gramineae, grasses, grassland formations
\end{abstract}

RESUMO - (Sinopse de Poaceae nas formações campestres do Parque Estadual do Guartelá, Estado do Paraná, Brasil). Poaceae é uma família cosmopolita que inclui espécies encontradas em formações florestais e campestres. O objetivo deste estudo foi realizar o primeiro levantamento florístico de Poaceae no Parque Estadual do Guartelá (PEG), um dos últimos remanescentes de vegetação nativa de formação campestre no Estado do Paraná, Brasil, e fornecer recursos para auxiliar na identificação dos gêneros e espécies. A pesquisa foi realizada com base em coletas a campo e busca na base de dados online Species Link. No PEG, Poaceae é representada por 29 gêneros e 54 espécies, sendo Paspalum L. (oito spp.), Andropogon L. (cinco spp.) e Eragrostis Wolf (quatro spp.) os gêneros mais ricos. O número de espécies de Poaceae no PEG foi incrementado em 29 novos registros. Além disso, cinco espécies foram classificadas como exóticas, cinco como endêmicas para o Brasil e duas foram consideradas menos preocupantes em relação à sua conservação. Também são apresentadas informações sobre distribuição, hábitat e status de conservação de cada espécie.

Palavras-chave: Campos Gerais, florística, Gramineae, gramíneas, formações campestres

\section{Introduction}

Poaceae is considered one of the greatest families among Angiosperms (Kawakita et al. 2016) and considerably important among the monocots, with approximately 12,074 species included in 771 genera (Soreng et al. 2015). In Brazil, there are 1,482 species recorded, distributed among 225 genera (Flora do Brasil 2020), while in Paraná there are 496 species recorded, distributed in 115 genera (Kaehler 2014). Due to their cosmopolitan dispersal, the family has a vast ecological range, with species occurring both in the forest as well as in grassland formations (Kawakita et al. 2016, Flora do Brasil 2020), predominating in open areas (Boldrini et al. 2008).

In the early Quaternary Period, the grassland formations covered a substantial part of the Paraná State. However, climate change (abundant precipitation) during the recent Quaternary favored the occupation of the land by forests, transforming the state into one of the richest areas of forest in Brazil, leaving the grassland formations restricted to some

1. Parte da Dissertação do primeiro Autor

2. Universidade Estadual do Oeste do Paraná, Departamento de Botânica, Rua Universitária, 2069, Bairro Jardim Universitário, 85819-110 Cascavel, PR, Brasil

3. Universidade Federal de Santa Catarina, Departamento de Botânica, Rua Roberto Sampaio Gonzaga, s/n, Bairro Trindade, $88040-900$ Florianópolis, SC, Brasil

4. Corresponding author: tainadsouzaa@gmail.com 
regions, as observed in the Campos Gerais do Paraná (Maack 2012, Labiak 2014).

The Parque Estadual do Guartelá (PEG) was created to ensure the survival of one of the last native and original vegetation with grassland formations of Paraná, in the Campos Gerais region (Federal decree-law no 2,329 of 24 September 1996). The PEG covers 798.97 ha and presents a high predominance of grassland physiognomy (rocky vegetational refuge, hygrophilous steppe and grassy-woody steppe), which, along with rock outcrops, constitutes $60.55 \%$ of the local area, in addition to the Mixed Ombrophilous Forest and Cerrado mosaic (Veloso et al. 1991, IAP 2002, Carmo 2006, Vasconcellos \& Rocha 2011, Labiak 2014, Maia \& Goldenberg 2014).

Even though Campos Gerais has a predominance of grassland physiognomies, which favors the occurrence of Poaceae species, taxonomic and floristic studies aimed at the family in this area and in Paraná are scarce, highlighting the lists of species Poaceae of Renvoize (1988), based on collections of Hatchbach's, and of Kaehler's (2014), based on herbarium collections and online database.

Quite a few of the floristic surveys conducted in Campos Gerais, mention the Poaceae taxa. Among them, it is worthwhile to highlight the works presented by Aguiar \& Vieira (2011) performed in the Parque Estadual do Cerrado; Ferreira \& Maranho (2011), Oliveira \& Maranho (2011), Freitas et al. (2011), Oliveira et al. (2011) and Silva et al. (2016) in the Parque Estadual Vila Velha, and, finally, IAP (2002) and Carmo (2006) in the PEG, where 40 taxa were indicated, of which seven were identified to genera level and one to family.

Considering that the park presents a relictual vegetation of Paraná (Vasconcellos \& Rocha 2011), possessing grand biological importance (Michelon \& Labiak 2013), this work constitutes the first floristic survey and the first to publish dichotomous keys for the Poaceae family in the grassland formations of PEG and Campos Gerais region.

\section{Material and methods}

The Parque Estadual do Guartelá (PEG) is located between the geographical coordinates $24^{\circ} 34^{\prime} 10.11^{\prime \prime} S$ and $50^{\circ} 15^{\prime} 56.54$ 'W in the Tibagi municipality, Paraná. It is inserted in the Campos Gerais region of the second plateau of Paraná, being part of the Devonian Scarp Environmental Protection Area (Federal decree-law n ${ }^{\circ}$ 1,231 of 27 Mach 1992) (IAP 2002, Carmo \& Assis
2012) (figure 1). According to Köppen (Alvares et al. 2014), the region's climate is Cfa (humid subtropical), with an influence of $\mathrm{Cfb}$ (humid temperate) and has average temperatures of $18^{\circ} \mathrm{C}$ (Carmo 2006, Carmo \& Assis 2012). The terrain is well-diverse varying from gently undulating to extremely hilly, and its soils are naturally poor and shallow, with high acidity levels and considerable water deficit (IAP 2002, Carmo et al. 2012).

For the collection of the Poaceae specimens, expeditions to the PEG were performed in March, June, August and October of 2015, and January and April of 2016, during five days each. All the areas of the grassland formation of PEG and its proximities were sampled, including the trails Básica $(5.280 \mathrm{~m})$ and Pinturas Rupestres $(7.500 \mathrm{~m})$, both with hygrophilous steppe and grassy-woody steppe (with wet sandy soil and drained sandy soil), and also rocky vegetational refuge (figure 1). Sampling was performed using the wide patrolling method described by Filgueiras et al. (1994).

The individuals collected were processed (Bridson \& Forman 2004) and deposited in the UNOP and FLOR herbaria (Thiers, continuously updated). The identification of the specimens was performed using specialized literature (Boldrini 1976, Sendulsky 1978, Sendulsky \& Soderstrom 1984, Davila 1988, Santos \& Boechat 1989, Flores \& Valls 1992, Boechat \& Longhi-Wagner 1995, Longhi-Wagner 1999, Guglieri \& Longhi-Wagner 2000, Boechat \& Longhi-Wagner 2001, Longhi-Wagner et al. 2001, Boechat 2005, Zuloaga \& Morrone 2005, Zanin \& Longhi-Wagner 2011, Zuloaga et al. 2011, Welker \& Longhi-Wagner 2012) and by comparison with specimens in the

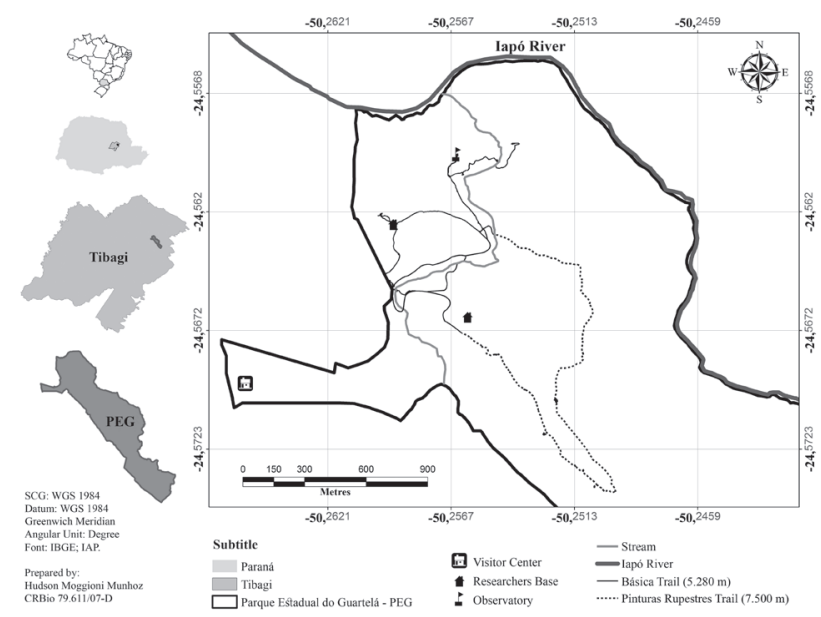

Figure 1. Location map and trails of the Parque Estadual do Guartelá, Tibagi, Paraná State, Brazil. 
herbaria MBM (Thiers, continuously updated). The spelling of the names follows the Lista de Espécies da Flora do Brasil (Flora do Brasil 2016) and the World Checklist of Selected Plant Families (WCSP 2016).

In addition to the field expeditions, searches were carried out in the Species Link online database (http://inct.splink.org.br) in order to verify collection records of the family for the PEG, mainly for species not found by the authors in the field. The species indicated were confirmed through visits to the FLOR and ICN herbaria and soon afterward were included in the keys. These are referenced next to the material examined.

The images used in the plates were captured using a video camera SC30 Olympus attached to a stereoscopic microscope trinocular SZX7 Olympus.

The conservation status was added only for the native species, using the IUCN Red List of Threatened Species (IUCN 2016) and the Centro Nacional de Conservação da Flora (CNCFlora 2016) criteria and categories.

\section{Results and Discussion}

In the Parque Estadual do Guartelá, 54 species of Poaceae, belonging to 29 genera were found: Agenium Nees (one sp.), Andropogon L. (five spp.), Aristida L. (three spp.), Axonopus P. Beauv. (three spp.), Ctenium Panz. (one sp.), Danthonia DC. (one sp.), Dichanthelium (Hitchc. \& Chase) Gould (one sp.), Eragrostis Wolf(four spp.), Eriochrysis P. Beauv. (two spp.), Homolepis Chase (one sp.), Hymenachne P. Beauv. (one sp.), Hyparrhenia Andersson ex E. Fourn. (one sp.), Ichnanthus P. Beauv. (one sp.), Melinis P. Beauv. (one sp.), Otachyrium Nees (one sp.), Panicum L. (one sp.), Parodiophyllochloa Zuloaga \& Morrone (one sp.), Paspalum L. (eight spp.), Pharus P. Browne (one sp.), Piptochaetium J. Presl (one sp.), Pseudechinolaena Stapf (one sp.), Rugoloa Zuloaga (one sp.), Setaria P. Beauv. (two spp.), Sorghastrum Nash (two spp.), Sporobolus R. Br. (one sp.), Steinchisma Raf. (two spp.), Trachypogon Nees (one sp.), Trichanthecium Zuloaga \& Morrone (two spp.) and Urochloa P. Beauv (three spp.).

Most of Poaceae species studied have been registered in other countries and in almost all Brazilian regions. However, five are considered endemic to Brazil (Eragrostis leucosticta, Eriochrysis villosa, Paspalum dasytrichium, Sorghastrum scaberrimum and Trichanthecium pseudisachne) (Flora do Brasil 2020) and Ctenium polystachyum, Dichanthelium sabulorum var. polycladum, Paspalum dasytrichum and Piptochaetium montevidense have restricted distributions to the Southeast and South of and Eriochrysis villosa in the South Brazil. In addition, five species are considered exotic (Melinis repens, Setaria sphacelata, Urochloa brizantha, $U$. decumbens and $U$. humidicola) and two are classified as of least concern to conservation (Agenium leptocladum and Hymenachne pernambucensis) (Flora do Brasil 2020).

Thirteen of the species found are considered ruderal (Andropogon bicornis, A. leucostachyus, Eragrostis bahiensis, E. neesii var. neesii, E. polytricha, Melinis repens, Paspalum polyphyllum, P. urvillei, Sporobolus indicus, Steinchisma laxum, Urochloa brizantha, U. decumbens and U. humidicola) (Sendulsky 1978, Boechat \& Longhi-Wagner 1995, Boechat \& Longhi-Wagner 2001, Longhi-Wagner et al. 2001, Zuloaga \& Morrone 2005, Zanin \& Longhi-Wagner 2011, Lorenzi 2014). The presence of these species in the PEG can be explained by the closely location of trails to the visitation and grazing areas.

The majority of Poaceae species in the grassland formations of PEG, mainly those belonging to Agenium, Aristida, Axonopus, Ctenium, Dichanthelium, Homolepis, Ichnanthus, Melinis, Panicum, Parodiophyllochloa, Pharus, Piptochaetium, Pseudechinolaena, Setaria, Sporobolus, Rugoloa, Trachypogon and Urochloa genera, were found in open areas with drained sandy soil and rock outcrops. Others studies with species of these genera highlight their preference for types of environment (Boldrini 1976, Boechat \& Longhi-Wagner 1995, LonghiWagner 1999, Guglieri \& Longhi-Wagner 2000, Longhi-Wagner et al. 2001, Boechat 2005). In the same way, the species study here belonging to the genera Danthonia, Eriochrysis, Hymenachne, Hyparrhenia, Otachyrium, Steinchisma and Trichanthecium were collected in wet sandy soil, as described by Sendulsky \& Soderstrom (1984), Santos \& Boechat (1989), Longhi-Wagner et al. (2001), Welker (2011) and Zuloaga et al. (2011). The species of the genera Andropogon, Eragrostis, Paspalum and Sorghastrum, study here and by others authors (Davila 1988, Boechat \& Longhi-Wagner 2001, Longhi-Wagner et al. 2001, Zuloaga \& Morrone 2005, Zanin \& Longhi-Wagner 2011), were found in both drained and wet soils.

With the data obtained, it was possible to contribute 11 genera and 29 species of Poaceae to PEG. Hence, the number previously indicated by the IAP (2002) and Carmo (2006) was 21 genera and 40 species, of these 
seven were identified only to genus level and one to family level. In addition, the occurrence of Homolepis glutinosa (Sw.) Zuloaga \& Soderstr., Paspalum erianthum Nees ex Trin. and Paspalum plicatulum Michx, recorded by IAP (2002), could not be confirmed by the absence of data in the herbarium where they were deposited. The same happened with Chascolytrum calotheca (Trin.) Essi, Longhi-Wagner \& Souza-Chies, Digitaria insularis (L.) Fedde, Anthaenantia lanata (Kunth) Benth. and Paspalum ellipticum Döll, indicated by Carmo (2006) to the PEG, in which, only $C$. calotheca appears in the online database Species Link, but when searching the herbarium there was no success on the confirmation. So, these species were not included in this work.

Ultimately, the abundance of species found, confirm what was already known, in that the Campos Gerais do Paraná, where PEG is located, has in its composition a dominance of grasses (Labiak 2014), which makes this family one of the most representative herbaceous components of the grassland formation in this region. We must also highlight that the species found on both drained and wet soils, emphasize the importance of the conservation of microenvironments that can be affected by touristic trails in the park.

Key to the Genera of Poaceae occurring in the Parque Estadual do Guartelá - Paraná State

(For the genera represented by a single species, this appears directly in the key)

1. Spikelets unisexual, the females and males different in size and shape (figure 2a); lemma of female spikelet membranous, with uncinate trichomes; leaves with twisting pseudopetiole

19.1. Pharus lappulaceus

1. Spikelets bisexual or if unisexual, the females and males are quite similar; lemma of female spikelet never with uncinate trichomes; leaves not twisted.

2. Articulation between rachilla and pedicel of spikelet located above glumes, in a way that glumes persist in the inflorescence after the fall of mature florets; spikelet basitonic (figure $2 b)$ or rarely mesotonic.

3. Upper glume awn dorsal; spikelet mesotony, with two basal sterile florets reduced to the lemmas, third floret fertile and the other apical florets sterile or rudimentary .... 5.1. Ctenium polystachyum

3. Upper glume without awn dorsal; spikelet basitony, with 1-numerous basal florets with bisexual flower, with or without apical florets sterile or rudimentary.

4. Lemma apex deeply 2-dentate, the two dent prolonged in lateral awns, with one more dorsal awn geniculate, with twisted column differentiated from the subule (figure $2 \mathrm{c}$ ) ...

6.1. Danthonia secundiflora

4. Lemma apex entire, muticate or with apical awn

5. Lemmas awn stiff, with margins convolute or involutes, enclosing the caryopsis in its interior.

6. Lemma cylindrical with apical awn 3-fid (figure 4b) 3. Aristida

6. Lemma wide-obovoid with a single apical awn often deciduous ... 20.1. Piptochaetium montevidense

5. Lemma membranous muticate, open, not enclosing the caryopsis in its interior

7. Spikelet with a single floret (figure $2 \mathrm{~d}$ ) . 25.1. Sporobolus indicus

7. Spikelet with 2-numerous florets 8. Eragrostis

2. Articulation between rachilla and pedicel of spikelet located below glumes, in a way that glumes are deciduous with the mature florets or branches with fragile rachis, disarticulating into units consisting of a sessile spikelet, one pedicellate spikelet and one articulation of rachis; spikelets acrotonic (figure 2e)

8. Spikelets arranged in pairs in each rachis node, one sessile and one pedicellate, usually falling into a set with rachis internode (figure 2f); lemma of upper floret hyaline, less consistent than the glumes

9. Inflorescence composed of a solitary floriferous branch at the apex of culm

10. Floriferous branches with the lower spikelets pairs homogamous (both with male flowers) and muticate; upper pairs heterogamous, with female sessile spikelet aristate and spikelet pedicellate male and muticate . 1.1. Agenium leptocladum

10. Floriferous branches with the spikelets pairs heterogamous throughout its length, with sessile spikelet male and muticate and pedicellate spikelet bisexual and aristate (figure $2 \mathrm{~g}$ ) 27.1. Trachypogon spicatus 
9. Inflorescence composed of two or more floriferous branches conjugate or subdigitate at the apex of culm (figure $2 \mathrm{~h}$ ), or inflorescence ramose oblong or corymbiform with spatheoles apparent (figure 2i), or inflorescence with long central axis with secondary branches adpressed or ascendent, spatheoles not apparent (figure 3c)

11. Spikelets pedicellate with bisexual flower and long plumose awn of 75-90 mm, falling solitarily at maturity, sessile spikelets persistent in the inflorescence .... 27.1. Trachypogon spicatus

11. Spikelets pedicellate absent (ex. Sorghastrum), rudimentary or bearing male or female flowers, blunt or aristulate, glabrous awn of $0.5-2.5 \mathrm{~mm}$, falling solitarily or along with the sessile spikelet and internode of the rachis at maturity

12. Panicle without a central axis well defined, with floriferous branches isolated, conjugate or digitate per spatheole (figure $2 \mathrm{~h}$ ), with spatheole apparent; spikelet pedicellate usually sterile and rudimentary, or developed bearing male flower

13. One floriferous branch per spatheole (figure 2i) 2.5. Andropogon (A. virgatus)

13. Two or more floriferous branches per spatheole

14. Floriferous branch with whitish hair, with more than 3 pairs of spikelets; spikelets pedicellate rudimentary (figure $3 \mathrm{a}$ ) (except in A. lateralis with developed pedicellate spikelets, but then sessile spikelets with awn up to $9 \mathrm{~mm}$ long)

2. Andropogon

14. Floriferous branch with yellow to rufescent hair, with 2-3 pairs of spikelets; spikelets pedicellate developed (sessile spikelets with awn of 18-23 mm long) (figure 3b)

12.1. Hyparrhenia bracteata

12. Panicle with a long and well defined central axis (figure 3c), with floriferous branches alternate along the persistent central axis, without apparent spatheole; spikelets pedicellate absent or developed bearing the female flower

15. Panicle pilose, with golden-brown dense trichomes (figure 3c); spikelets pedicellate developed bearing a female flower 9. Eriochrysis 15.Panicle glabrous; spikelet pedicellate absent, only the pedicel present

24. Sorghastrum

8. Spikelets isolated, rarely binate or in groups, all pedicellate, falling separately; lemma of upper floret coriaceous to cartilaginous, never hyaline, firmer than the glumes (except in Melinis, whose upper floret is membranous, however it presents spikelets with long rose trichomes)

16. Spikelets surrounded by a set of involucral bristles at the base (figure $3 \mathrm{~d}$ ) 23. Setaria

16. Spikelets without involucral bristles at the base

17. Spikelets pilose, with long rose trichomes (figure 3e); upper floret membranous ... 14.1. Melinis repens 17. Spikelets glabrous, with short trichomes, not rose; upper floret cartilaginous or coriaceous

18. Upper lemma with two aliform lateral appendages at the base of the ventral region

13.1. Ichnanthus inconstans

18. Upper lemma without aliform lateral appendages at the base of the ventral region

19. Inflorescence in panicle of unilateral branches spiciform or contracted, conjugate, subconjugate, alternate-distichous, digitate or subverticellate 20. Upper glume provided with uncinate trichomes at maturity

21.1. Pseudechinolaena polystachya

20. Upper glume devoid of uncinate trichomes at maturity 21 . Lower glume present

22. Lower palea absent; robust plants higher than $160 \mathrm{~cm}$, marshy 11.1. Hymenachne pernambucensis

22. Lower palea present; plants less than $130 \mathrm{~cm}$ high, campos or dry environments partially shaded 
23. Ligule absent

22.1. Rugoloa pilosa

23. Ligule present

24. Spikelets 4-5 × 1.8-2.5 mm; upper floret transversely rugulose to finely striate (figure $3 \mathrm{f}$ ) . 29. Urochloa

24. Spikelets 1.1-1.7 $\times$ 0.5-0.8 mm; upper floret smooth (figure 3g) 26.2. Steinchisma (S. laxum)

21. Lower glume absent

25. Glume's back and upper lemma abaxial to the rachis

4. Axonopus

25. Glume's back and upper lemma adaxial to the rachis 18. Paspalum

19. Inflorescence in typical panicle, lax, open, subcontracted to contracted

26. Upper and lower glume of subequal length between each other

27. Glumes reaching up to half of spikelet length; lower palea with keels expanding at maturity, forming whitish wings; upper floret black at maturity 15.1. Otachyrium versicolor

27. Glumes subequal to spikelets in length; lower palea not expanded at maturity, without wings; upper floret stramineous at maturity

10.1. Homolepis villaricensis

26. Lower glume always shorter than the superior

28. Panicle contracted to subcontracted, with primary branches adpressed to the main axis; lower palea expanded at maturity ... 26.1. Steinchisma (S. decipiens)

28. Panicle lax; lower palea absent or not expanded at maturity 29. Lower palea absent 17.1. Parodiophyllochloa pantricha

29. Lower palea present

30. Spikelets 5.5-6.3 mm long; upper lemma with tufts of long trichomes laterally and at the base (figure $3 \mathrm{~h}$ )

16.1. Panicum olyroides var. hirsutum

30. Spikelets 1.3-2.5 mm long; upper lemma without tufts of long trichomes

31.Ligule membranous ciliate, shortly membranous at base, and lengthy ciliate above (figure 3i); upper glume and lower lemma 7-9 veined 7.1. Dichanthelium sabulorum var. polycladum

31.Ligule membranous, shortly lacinate at apex; upper glume and lower glume 3-5 veined

28. Trichanthecium

1. Agenium Nees in J. Lindley, Intr. Nat. Syst. Bot., ed. 2: 447.1836.

1.1. Agenium leptocladum (Hack.) Clayton Kew Bull. 27(3): 447. 1972.

For figures, see Longhi-Wagner et al. (2001)

Distribution: South America. In Brazil, it occurs in the Central-West, Southeast and South regions (Clayton 1972, Renvoize 1988, Longhi-Wagner et al. 2001, Flora do Brasil 2020).

Habitat: Grassland with drained sandy soil.

Conservation: LC. Native.

Specimens examined: BRAZIL. Paraná: Tibagi, Parque Estadual do Guartelá, 05-III-2004, M.R.B. do Carmo 814 (ICN - additional material).
2. Andropogon L., Sp. P1. 2: 1045. 1753.

Key to the Andropogon species of Parque Estadual do Guartelá

1. Only a single branch per spatheole (figure

2i) 2.5. A. virgatus

1. Two or more branches per spatheole

2. Spikelets pedicellate all sterile, usually reduced or rudimentary (figure $4 \mathrm{a}$ ) 3. Spikelets sessile $4-5 \mathrm{~mm}$ long, with awns 17-23 mm long. Callus of sessile spikelet with longer trichomes reaching 1.2-4 mm long (figure 3a) ........ 2.4. A. macrothrix 3. Spikelets sessile 2.2-3.1 mm long, with awns 1-3.2 mmlong, ocasionally spikelets awnless in the same inflorescence;. Callus of sessile spikelet with longer trichomes reaching 4.2-9 mm long (figure 4a) . 2.3. A. leucostachyus 
2. Spikelets pedicellate, all of them or at least in part of the inflorescence, developed and staminate

4. Inflorescence lax, long; units of terminal inflorescence or terminal and axillary with 3-5 simple floriferous branches or secondary branches, subequal or unequal in length (figure 2h) 2.2. A. lateralis

4. Inflorescence corymbiform, clustered at the floriferous culms apex; inflorescence units with 2(3) simple floriferous branches and equal or subequal in length 2.1. A. bicornis

2.1. Andropogon bicornis L., Sp. Pl. 2: 1046. 1753.

For figures, see Longhi-Wagner et al. (2001) or Zanin \& Longhi-Wagner (2011).

Distribution: Neotropics. In Brazil, it occurs in the North, Northeast, Central-West, Southeast and South regions (Renvoize 1988, Longhi-Wagner et al. 2001, Zanin \& Longhi-Wagner 2011, Flora do Brasil 2020).

Habitat: Grassland with drained and wet sandy soil. Ruderal.

Conservation: DD. Native.

Specimens examined: BRAZIL. Paraná: Tibagi, Parque Estadual do Guartelá, 26-III-2015, T. Souza et al. 3, 4 (UNOP).

\subsection{Andropogon lateralis Nees in Mart., Fl. Bras.}

Enum. Pl. 2(1): 329. 1829.

\section{Figures $2 \mathrm{f}, \mathrm{h}$}

Distribution: South America. In Brazil, it occurs in the North, Northeast, Central-West, Southeast and South regions (Renvoize 1988, Longhi-Wagner et al. 2001, Zanin \& Longhi-Wagner 2011, Flora do Brasil 2020).

Habitat: Grassland with wet sandy soil.

Conservation: DD. Native.

Specimens examined: BRAZIL. Paraná: Tibagi, Parque Estadual do Guartelá, 26-X-2015, T. Souza et al. 5 (UNOP).

\subsection{Andropogon leucostachyus Kunth in Humboldt,}

Bonpland \&Kunth, Nov. Gen. Sp. 1: 187. 1816.

Figure $4 \mathrm{a}$

Distribution: Mexico and Antilles to Argentina. In Brazil, it occurs in the North, Northeast, Central-West,
Southeast and South regions (Renvoize 1988, LonghiWagner et al. 2001, Zanin \& Longhi-Wagner 2011, Flora do Brasil 2020).

Habitat: Grassland with drained sandy soil. Ruderal.

Conservation: DD. Native.

Specimens examined: BRAZIL. Paraná: Tibagi, Parque Estadual do Guartelá, 26-VIII-2015, T. Souza et al. 8, 9 (UNOP), 26-X-2015, T. Souza et al. 10, 11 (UNOP).

2.4. Andropogon macrothrix Trin., Mém. Acad. Imp. Sci. St.-Pétersbourg, Sér. 6, Sci. Math. 2: 270. 1832.

Figure $3 \mathrm{a}$

Distribution: South America. In Brazil, it occurs in the Northeast, Central-West, Southeast and South regions (Longhi-Wagner et al. 2001, Zanin \& Longhi-Wagner 2011, Flora do Brasil 2020).

Habitat: Grassland with wet sandy soil.

Conservation: DD. Native.

Specimens examined: BRAZIL. Paraná: Tibagi, Parque Estadual do Guartelá, 26-III-2015, T. Souza et al. 7 (UNOP), 26-X-2015, T. Souza et al. 6 (UNOP).

2.5. Andropogon virgatus Desv. in Ham., Prodr. P1. Ind. Occid.: 9. 1825.

Figure $2 \mathrm{i}$

Distribution: South and Central America. In Brazil, it occurs in the North, Northeast, Central-West, Southeast and South regions (Zanin \& Longhi-Wagner 2011, Flora do Brasil 2020).

Habitat: Grassland with wet sandy soil.

Conservation: DD. Native.

Specimens examined: BRAZIL. PARANÁ: Tibagi, Parque Estadual do Guartelá, 26-III-2015, T. Souza et al. 12 (UNOP), 26-VIII-2015, T. Souza et al. 13 (UNOP), 21-I-2016, T. Souza et al. 14 (UNOP).

3. Aristida L., Sp. P1.: 82. 1753.

Key to the Aristida species of Parque Estadual do Guartelá

1. Lemma apex without a twisted column; awns $16-20 \mathrm{~cm}$ long, starting directly from the lemma apex (figure 4b) 3.1. A. jubata

1. Lemma apex with a twisted column (figure 4c); awns 0.8-4.2 cm long, starting directly from the column apex 
2. Column 30-42 mm long; awns straight or flexuous at base; acute callus 1-1.4 mm long 3.2. A. megapotamica

2. Column 1.8-2 mm long; awns twisted and coiled at base; obtuse callus $0.2-0.5 \mathrm{~mm}$ long (figure 4c) 3.3. A. recurvata

3.1. Aristida jubata (Arechav.) Herter, Revista Sudamer. Bot. 9(4): 98. 1953.

Figure $4 b$

Distribution: South America. In Brazil, it occurs in the Central-West, Southeast and South regions (LonghiWagner 1999, Longhi-Wagner et al. 2001, Flora do Brasil 2020).

Habitat: Grassland with drained sandy soil and rock outcrops.

Conservation: DD. Native.

Specimens examined: BRAZIL. Paraná: Tibagi, Parque Estadual do Guartelá, 26-VIII-2015, T. Souza et al. 15 (UNOP).

\subsection{Aristida megapotamica Spreng., Syst. Veg. 4(2):}

31. 1827.

For figures, see Longhi-Wagner (1999) or LonghiWagner et al. (2001).

Distribution: South America. In Brazil, it occurs in the Northeast, Central-West, Southeast and South regions (Renvoize 1988, Longhi-Wagner 1999, LonghiWagner et al. 2001, Flora do Brasil 2020).

Habitat: Grassland with drained sandy soil.

Conservation: DD. Native.

Specimens examined: BRAZIL. Paraná: Tibagi, Parque Estadual do Guartelá, 2-VI-2015, T. Souza et al. 16 (UNOP).

3.3. Aristida recurvata Kunth in Humboldt, Bonpland

\& Kunth, Nov. Gen. Sp. 1: 123. 1816.

Figure 4c

Distribution: South and Central America. In Brazil, it occurs in the North, Northeast, Central-West, Southeast and South regions (Renvoize 1988, LonghiWagner 1999, Longhi-Wagner et al. 2001, Flora do Brasil 2020).

Habitat: Grassland with drained sandy soil and rock outcrops.

Conservation: DD. Native.
Specimens examined: BRAZIL. Paraná: Tibagi, Parque Estadual do Guartelá, 26-VIII-2016, T. Souza et al. 84 (UNOP).

4. Axonopus P.Beauv., Ess. Agrostogr.: 12. 1812.

Key to the Axonopus species of Parque Estadual do Guartelá

1. Branches of the inflorescence hispid to setose in all extesion, with tuberculate trichomes (figure 4d) ..................... 4.1. A. brasiliensis

1. Branches of the inflorescence glabrous or sparsely scabrous, or with trichomes not tuberculate at the apex of pedicels, usually at the spikelets base

2. Leaf blades filiform involute; upper floret 1.6-2.2 mm long; upper glume and lower lemma 5-7-veined, veins evident and glabrous or with short trichomes between veins, the central vein always present ........................................ 4.3. A. siccus

2. Leaf blades flat; upper floret 2.4-3.2 mm long; upper glume and lower lemma 2-4 veined, veins less evident and densely pilose, central vein usually inconspicous (figure 4e) 4.2. A. marginatus

4.1. Axonopus brasiliensis (Spreng.) Kuhlm., Commiss. Linhas Telegr. Estratég. Matto Grosso Amazonas 5(11): 47. 1922.

Figure 4d

Distribution: Paraguay and in Brazil it occurs in the North, Northeast, Central-West, Southeast and South regions (Renvoize 1988, Longhi-Wagner et al. 2001, Flora do Brasil 2020).

Habitat: Grassland with drained sandy soil.

Conservation: DD. Native.

Specimens examined: BRAZIL. Paraná: Tibagi, Parque Estadual do Guartelá, 2-VI-2015, T. Souza et al. 17, 18, 19 (UNOP), 26-VIII-2015, T. Souza et al. 20, 21 (UNOP), 26-X-2015, T. Souza et al. 22 (UNOP).

4.2. Axonopus marginatus (Trin.) Chase ex Hitchc., Contr. U. S. Natl. Herb. 17(3): 226. 1913. Figure 4e

Distribution: Bolivia, Paraguay and in Brazil it occurs in the North, Northeast, Central-West, Southeast and South regions (Renvoize 1988, Longhi-Wagner et al. 2001, Flora do Brasil 2020). 


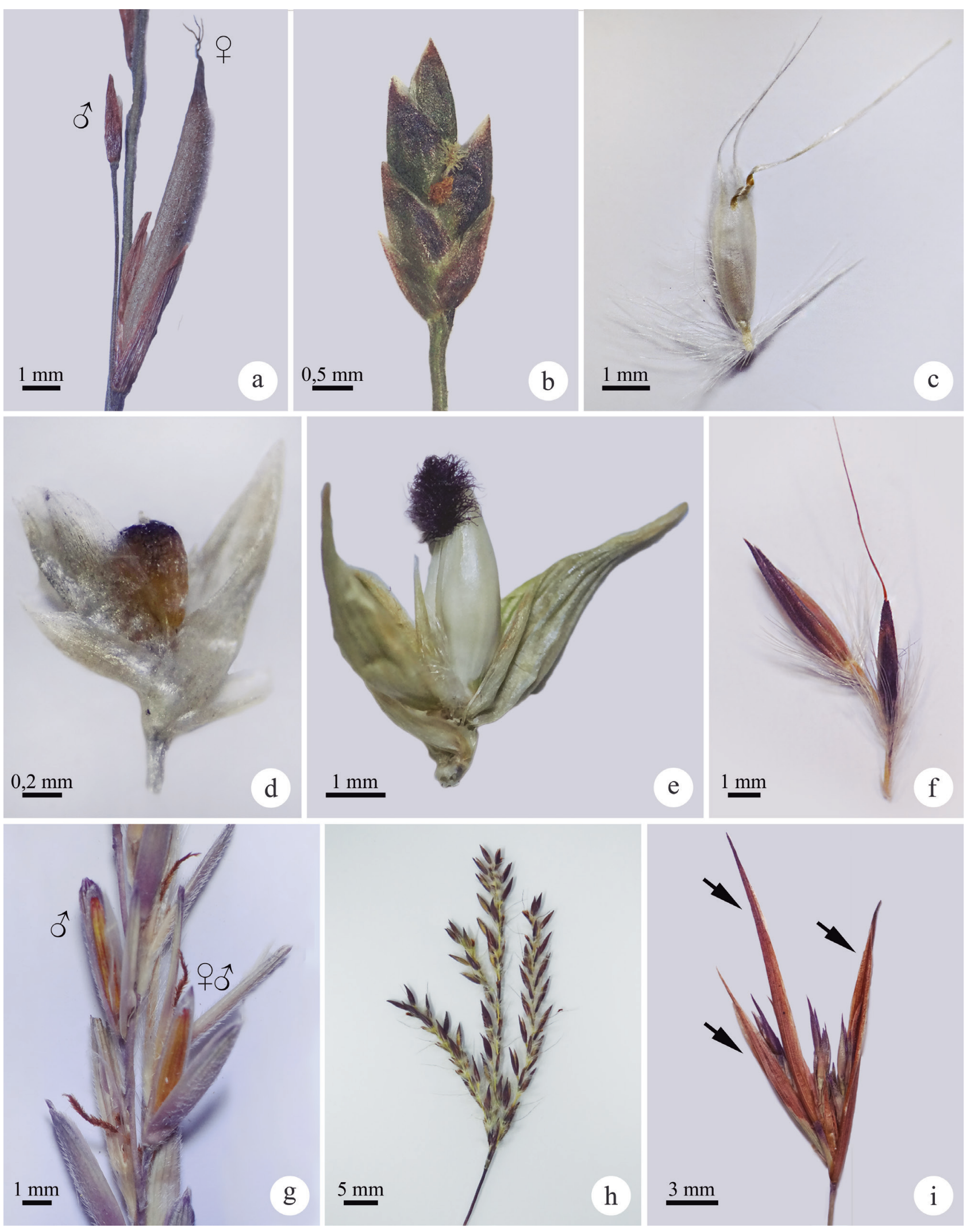

Figure 2. a. Pharus lappulaceus, inflorescence branch. b. Eragrostis polytricha, spikelet. c. Danthonia secundiflora, lemma, dorsal view. d. Sporobolus indicus, spikelet. e. Panicum olyroides var. hirsutum, spikelet. f. Andropogon lateralis, detail of a fragment of the inflorescence branch. g. Trachypogon spicatus, detail of a fragment of the inflorescence branch. h. Andropogon lateralis, inflorescence unit. i. A. virgatus, detail of a fragment of the inflorescence branch, showing one floriferous branch per spatheole (arrows). 
Habitat: Grassland with drained sandy soil.

Conservation: DD. Native.

Specimens examined: BRAZIL. Paraná: Tibagi, Parque Estadual do Guartelá, 2-VI-2015, T. Souza et al. 23, 24 (UNOP).

4.3. Axonopus siccus (Nees) Kuhlm., Commiss. Linhas Telegr. Estratég. Matto Grosso Amazonas 67(11): 87. 1922.

For figures, see Longhi-Wagner et al. (2001).

Distribution: South America. In Brazil, it occurs in the North, Northeast, Central-West, Southeast and South regions (Renvoize 1988, Longhi-Wagner et al. 2001, Flora do Brasil 2020).

Habitat: Grassland with drained sandy soil.

Conservation: DD. Native.

Specimens examined: BRAZIL. Paraná: Tibagi, Parque Estadual do Guartelá, 26-III-2015, T. Souza et al. 25, 26 (UNOP).

5. Ctenium Panz., Ideen Revis. Gräser: 38. 1813.

5.1. Ctenium polystachyum Balansa, Bull. Soc. Bot. France 32: 244. 1885.

For figures, see Longhi-Wagner et al. (2001).

Distribution: South America. In Brazil, it occurs in the Southeast and South regions (Renvoize 1988, LonghiWagner et al. 2001, Flora do Brasil 2020).

Habitat: Grassland with drained sandy soil.

Conservation: DD. Native.

Specimens examined: BRAZIL. Paraná: Tibagi, Parque Estadual do Guartelá, 24-III-2004, M.R.B. do Carmo 840 (ICN - additional material).

6. Danthonia DC., Fl. Franç., 3: 32. 1805.

6.1. Danthonia secundiflora J.Pres1, Reliq. Haenk. 1: 255.1830.

Figure 2c

Distribution: South America. In Brazil, it occurs in the Northeast, Southeast and South regions (Renvoize 1988, Santos \& Boechat 1989, Flora do Brasil 2020).

Habitat: Grassland with wet sandy soil.

Conservation: DD. Native.
Specimens examined: BRAZIL. PARAnÁ: Tibagi, Parque Estadual do Guartelá, 2-VI-2015, T. Souza et al. 27 (UNOP).

7. Dichanthelium (Hitchc. \& Chase) Gould, Brittonia 26: 59. 1974.

7.1. Dichanthelium sabulorum (Lam.) Gould \& C.A. Clark var. polycladum (Ekman) Zuloaga, Amer. J. Bot. 90: 817. 2003.

Figure 3i

Distribution: South America. In Brazil, it occurs in the Southeast and South regions (Guglieri \& LonghiWagner 2000, Longhi-Wagner et al. 2001, Flora do Brasil 2020).

Habitat: Grassland with drained sandy soil.

Conservation: DD. Native.

Specimens examined: BRAZIL. Paraná: Tibagi, Parque Estadual do Guartelá, 26-X-2015, T. Souza et al. 77 (UNOP).

8. Eragrostis Wolf, Gen. Pl.: 23. 1776.

Key to the Eragrostis species of Parque Estadual do Guartelá

1. Plants glandulous, glands present in pedicels usually with ring-shaped (figure 4f)

2. Leaf blade dimorphic, mostly recurved, brown-reddish and other ascendent greenish; caryopsis largely oblong, grooved ..... 8.2. E. leucosticta

2. Leaf blade isomorphic, flat to involute; caryopsis largely elliptical, not grooved 8.3. E. neesii var. neesii

1. Plants eglandulous, glands absent in the pedicels

3. Leaf blade dimorphic 8.2. E. leucosticta

3. Leaf blade isomorphic

4. Sheath densely pilose on the surface; pedicels with pilose axils (figure 4g); stamens 3 8.4. E. polytricha

4. Sheath glabrous or with trichomes subdense to sparse on the surface; pedicels with glabrous axils (figure $4 \mathrm{~h}$ ); stamens 2 8.1. E. bahiensis

8.1. Eragrostis bahiensis Schrad. ex Schult., Mant. 2: 318.1824.

Figure $4 \mathrm{~h}$ 


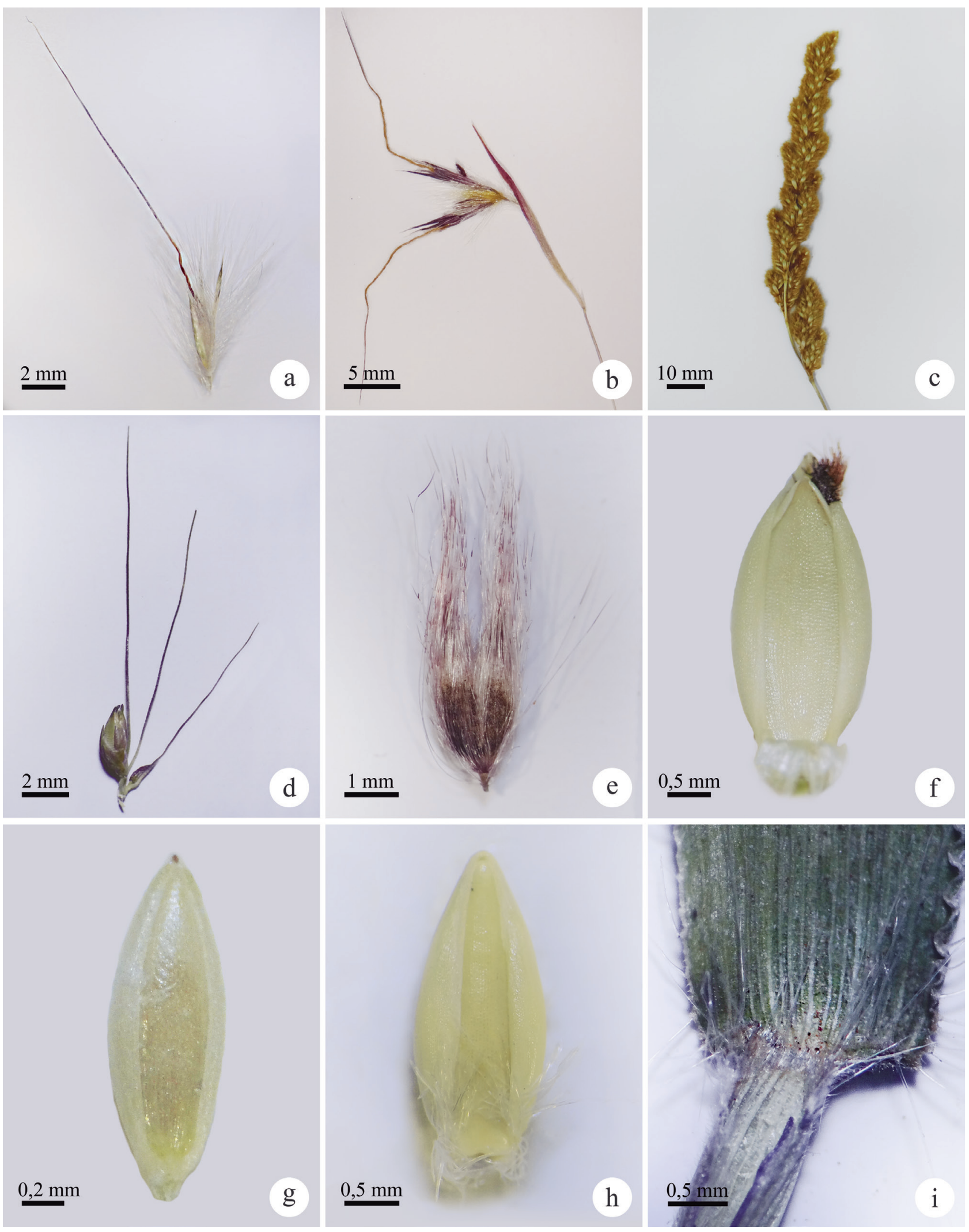

Figure 3. a. Andropogon macrothrix, sessile and pedicellate (rudimentary) spikelets. b. Hyparrhenia bracteata, inflorescence branch. c. Eriochrysis cayennensis, inflorescence. d. Setaria scabrifolia, spikelet with involucral bristles. e. Melinis repens, spikelet. f. Urochloa decumbens, upper floret, palea view. g. Steinchisma laxum, upper floret, palea view. h. Panicum olyroides var. hirsutum, upper floret, palea view. i. Dichanthelium sabulorum var. polycladum, leaf highlighting the ligular region. 


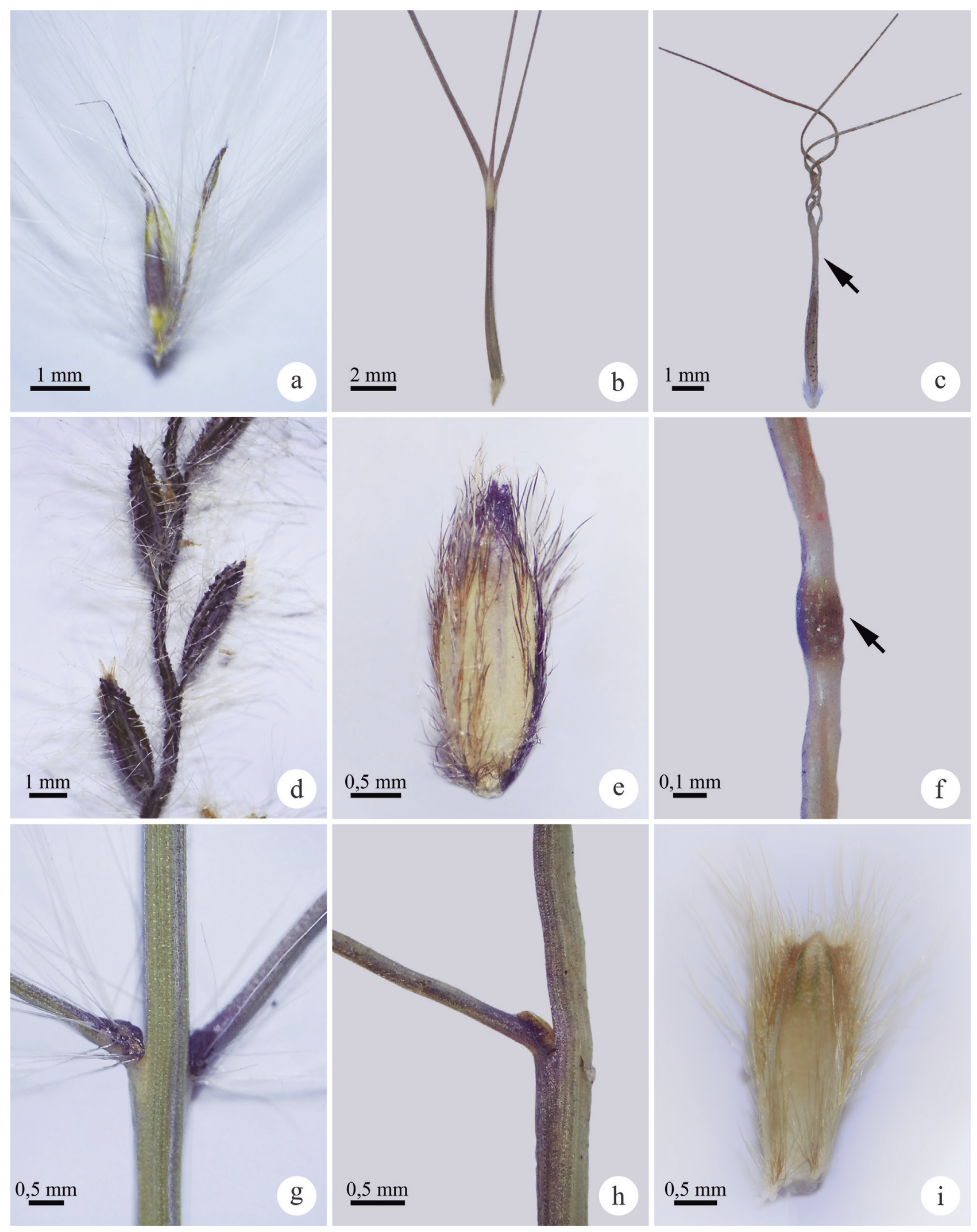

Figure 4. a. Andropogon leucostachyus, sessile and pedicellate (rudimentary) spikelets. b. Aristida jubata, lemma. c. A. recurvata, lemma, showing detail of the column (arrow). d. Axonopus brasiliensis, detail of a fragment of the inflorescence branch. e. A. marginatus, spikelet. f. Eragrostis leucosticte, pedicel, showing detail of the ring (arrow). g. E. polytricha, pilose pedicelar base. h. E. bahiensis, glabrous pedicelar base. i. Eriochrysis cayennensis, sessile spikelet, lower glume view. 
Distribution: North, Central and South America. In Brazil, it occurs in the North, Northeast, Central-West, Southeast and South regions (Renvoize 1988, Boechat \& Longhi-Wagner 2001, Longhi-Wagner et al. 2001, Flora do Brasil 2020).

Habitat: Grassland with wet sandy soil. Ruderal.

Conservation: DD. Native.

Specimens examined: BRAZIL. Paraná: Tibagi, Parque Estadual do Guartelá, 26-XIII-2015, T. Souza et al. 29, 30 (UNOP), 21-I-2016, T. Souza et al. 31 (UNOP).

\subsection{Eragrostis leucosticta Nees ex Döll in Mart., Fl.}

Bras. 2(3): 144. 1878.

Figure $4 \mathrm{f}$

Distribution: endemic to Brazil, occurring in the Northeast, Central-West, Southeast and South regions (Boechat \& Longhi-Wagner 2001, Longhi-Wagner et al. 2001, Flora do Brasil 2020).

Habitat: Grassland with drained sandy soil.

Conservation: DD. Native.

Specimens examined: BRAZIL. Paraná: Tibagi, Parque Estadual do Guartelá, 26-III-2015, T. Souza et al. 32, 33 (UNOP), 26-X-2015, T. Souza et al. 34 (UNOP).

8.3. Eragrostis neesii Trin. var. neesii Trin., Mém. Acad. Imp. Sci. St.-Pétersbourg, Sér. 6, Sci. Math. 1: 405.1830.

For figures, see Boechat \& Longhi-Wagner (2001) or Longhi-Wagner et al. (2001).

Distribution: South America. In Brazil, it occurs in the Northeast, Central-West, Southeast and South regions (Renvoize 1988, Boechat \& Longhi-Wagner 2001, Longhi-Wagner et al. 2001, Flora do Brasil 2020).

Habitat: Grassland with wet sandy soil. Ruderal.

Conservation: DD. Native.

Specimens examined: BRAZIL. Paraná: Tibagi, Parque Estadual do Guartelá, 26-VIII-2015, T. Souza et al. 35 (UNOP).

8.4. Eragrostis polytricha Nees, Agrost. Bras. in Mart., Fl. Bras. Enum. P1. 2: 507. 1829.

Figures $2 b ; 4 g$

Distribution: North, Central and South America. In Brazil, it occurs in all (Renvoize 1988, Boechat \&
Longhi-Wagner 2001, Longhi-Wagner et al. 2001, Flora do Brasil 2020).

Habitat: Grassland with drained sandy soil and rock outcrops. Ruderal.

Conservation: DD. Native.

Specimens examined: BRAZIL. Paraná: Tibagi, Parque Estadual do Guartelá, 26-III-2015, T. Souza et al. 37 (UNOP), 26-VIII-2015, T. Souza et al. 36 (UNOP).

9. Eriochrysis P. Beauv., Ess. Agrostogr.: 8. 1812.

Key to the Eriochrysis species of the Parque Estadual do Guartelá.

1. Lower glume of sessile spikelet with truncate apex, trilobed (figure 4i) ... 9.1. E. cayennensis

1. Lower glume of sessile spikelet with acute to subacute apex, non-lobed or with inconspicuous lobes 9.2. E. villosa

9.1. Eriochrysis cayennensis P. Beauv., Ess. Agrostogr.: 8. 1812.

Figures $3 \mathrm{c}$; $4 \mathrm{i}$

Distribution: North, Central and South America. In Brazil, it occurs in the North, Northeast, Central-West, Southeast and South regions (Renvoize 1988, LonghiWagner et al. 2001, Filgueiras 2003, Welker 2011, Welker \& Longhi-Wagner 2012, Flora do Brasil 2020).

Habitat: Grassland with wet sandy soil.

Conservation: DD. Native.

Specimens examined: BRAZIL. Paraná: Tibagi, Parque Estadual do Guartelá, 26-III-2015, T. Souza et al. 38 (UNOP).

9.2. Eriochrysis villosa Swallen, Phytologia 14(2): 90. 1966.

For figures, see Welker (2011) or Welker \& LonghiWagner (2012).

Distribution: endemic to Brazil, occurring in the South region (Welker 2011, Welker \& Longhi-Wagner 2012, Flora do Brasil 2020).

Habitat: Grassland with wet sandy soil.

Conservation: DD. Native.

Specimens examined: BRAZIL. PARAnÁ: Tibagi, Parque Estadual do Guartelá, 4-XII-2003, M.R.B. do Carmo 450 (ICN - additional material). 
10. Homolepis Chase, Proc. Biol. Soc. Washington 24: 146. 1911.

10.1. Homolepis villaricensis (Mez) Zuloaga \& Soderstr., Smiths. Contr. Bot. 59: 29. 1985.

For figures, see Longhi-Wagner et al. (2001).

Distribution: South America. In Brazil, it occurs in the Central-West, Southeast and South regions (LonghiWagner et al. 2001, Flora do Brasil 2020).

Habitat: Grassland with drained sandy soil and rock outcrops.

Conservation: DD. Native.

Specimens examined: BRAZIL. Paraná: Tibagi, Parque Estadual do Guartelá, 21-I-2016, T. Souza et al. 39 (UNOP), 10-II-2004, M.R.B. do Carmo 684 (ICN - additional material).

11. Hymenachne P.Beauv., Ess. Agrostogr.: 48. 1812.

\subsection{Hymenachne pernambucensis (Spreng.)} Zuloaga, Amer. J. Bot. 90(5): 817. 2003.

For figures, see Guglieri \& Longhi-Wagner (2000) or Longhi-Wagner et al. (2001).

Distribution: South America. In Brazil, it occurs in the North, Northeast, Central-West, Southeast and South regions (Guglieri \& Longhi-Wagner 2000, LonghiWagner et al. 2001, Flora do Brasil 2020).

Habitat: Grassland with wet sandy soil.

Conservation: DD. Native.

Specimens examined: BRAZIL. Paraná: Tibagi, Parque Estadual do Guartelá, 2-VI-2015, T. Souza et al. 40 (UNOP).

12. Hyparrhenia Andersson ex E.Fourn., Mexic. Pl. 2: 51, 67. 1886.

12.1. Hyparrhenia bracteata (Humb. \& Bonpl. ex Willd.) Stapf in Oliv., Fl. Trop. Afr. 9: 360. 1919. Figure $3 b$

Distribution: In the tropical regions of America and Africa. In Brazil, it occurs in the Central-West, Southeast and South regions (Renvoize 1988, LonghiWagner et al. 2001, Flora do Brasil 2020).

Habitat: Grassland with wet sandy soil.

Conservation: DD. Native.
Specimens examined: BRAZIL. Paraná: Tibagi, Parque Estadual do Guartelá, 26-III-2015, T. Souza et al. 44 (UNOP).

13. Ichnanthus P.Beauv., Ess. Agrostogr.: 56, Pl. 12, f. 1.1812 .

13.1. Ichnanthus inconstans (Trin. ex Nees) Döll in Mart., Fl. Bras. 2(2): 284. 1877.

For figures, see Longhi-Wagner et al. (2001) or Boechat (2005).

Distribution: South America. In Brazil, it occurs in the Northeast, Central-West, Southeast and South regions (Renvoize 1988, Longhi-Wagner et al. 2001, Boechat 2005, Flora do Brasil 2020).

Habitat: Edge of Mixed Ombrophilous Forest with drained sandy soil.

Conservation: DD. Native.

Specimens examined: BRAZIL. Paraná: Tibagi, Parque Estadual do Guartelá, 21-I-2016, T. Souza et al. 41 (UNOP).

14. Melinis P.Beauv., Ess. Agrostogr.: 54. 1812.

14.1. Melinis repens (Willd.) Zizka, Biblioth. Bot. 138: 55. 1988.

Figure 3e

Distribution: Netropics. In Brazil, it occurs in the Northeast, Central-West, Southeast and South regions (Renvoize 1988, Longhi-Wagner et al. 2001, Flora do Brasil 2020).

Habitat: Grassland with drained sandy soil. Ruderal. Conservation: Exotic.

Specimens examined: BRAZIL. Paraná: Tibagi, Parque Estadual do Guartelá, 21-VI-2015, T. Souza et al. 42 (UNOP), 26-X-2015, T. Souza et al. 43 (UNOP).

15. Otachyrium Nees, Fl. Bras. Enum. Pl. 2(1): 271. 1829.

15.1. Otachyrium versicolor (Döll) Henrard, Blumea 4(3): 511. 1941.

For figures, see Sendulsky \& Soderstrom (1984) or Longhi-Wagner et al. (2001).

Distribution: Central and South America. In Brazil, it occurs in the North, Northeast, Central-West, 
Southeast and South regions (Sendulsky \& Soderstrom 1984, Renvoize 1988, Longhi-Wagner et al. 2001, Flora do Brasil 2020).

Habitat: Grassland with wet sandy soil.

Conservation: DD. Native.

Specimens examined: BRAZIL. Paraná: Tibagi, Parque Estadual do Guartelá, 26-III-2015, T. Souza et al. 45, 46 (UNOP), 26-VIII-2015, T. Souza et al. 48 (UNOP), 21-I-2016, T. Souza et al. 47 (UNOP).

\section{Panicum L., Sp. Pl.: 55 (1753).}

16.1. Panicum olyroides var. hirsutum Henrard, Meded. Rijks-Herb. 40: 52. 1921.

Figures 2e; $3 \mathrm{~h}$

Distribution: South America. In Brazil, it occurs in the North, Northeast, Central-West, Southeast and South regions (Renvoize 1988, Guglieri \& LonghiWagner 2000, Longhi-Wagner et al. 2001, Flora do Brasil 2020).

Habitat: Grassland with drained sandy soil.

Conservation: DD. Native.
Specimens examined: BRAZIL. PAranÁ: Tibagi, Parque Estadual do Guartelá, 21-I-2016, T. Souza et al. 49 (UNOP).

17. Parodiophyllochloa Zuloaga \& Morrone, Syst. Bot. 33(1): 69. 2008.

\subsection{Parodiophyllochloa pantricha (Hack.) Zuloaga} \& Morrone, Syst. Bot. 33: 73. 2008.

For figures, see Guglieri \& Longhi-Wagner (2000) or Longhi-Wagner et al. (2001).

Distribution: Central and South America. In Brazil, it occurs in the Northeast, Central-West, Southeast and South regions (Renvoize 1988, Guglieri \& LonghiWagner 2000, Longhi-Wagner et al. 2001, Flora do Brasil 2020).

Habitat: Edge of Mixed Ombrophilous Forest with drained sandy soil.

Conservation: DD. Native.

Specimens examined: BRAZIL. ParanÁ: Tibagi, Parque Estadual do Guartelá, 21-I-2016, T. Souza et al. 79 (UNOP).

18. Paspalum L., Syst. Nat. ed. 10, 2: 855. 1759.

Key to the Paspalum species of the Parque Estadual do Guartelá.

1. Spikelets with upper glume winged, with cordate base (figure 5a) ...

18.2. P. cordatum

1. Spikelets with upper glume not winged, without cordate base

2. Inflorescence with 2 branches conjugate or slightly subconjugate (figure 5b), rarely a third below; plants with horizontal supraterraneous rhizomes, entirely covered by old sheath .... 18.5. P. notatum

2. Inflorescence with 1 to many alternate branches; plants without rhizomes or if with rhizomes, then not supraterraneous

3. Upper glume and lower lemma with long tuberculate trichomes (longer than $2 \mathrm{~mm}$ ) on margins (figure 5c) 18.6. P. polyphyllum

3. Upper glume and lower lemma glabrous or with trichomes not tuberculate, silky, delicate and short (shorter than $2 \mathrm{~mm}$ ) on margins.

4. Upper floret dark brown to black; lower lemma with transversal undulations between the central and lateral veins (= lemma plicate)

5. Prefoliation conduplicate; base of plant with leaf sheaths keeled and strongly flattened

18.1. P. compressifolium

5. Prefoliation convolute; base of plant with leaf sheaths not keeled and neither strongly flattened ..... 18.7. P. rojasii

4. Upper floret white, stramineous or light brown; lower lemma without transversal undulations (= lemma smooth)

6. Upper glume and lower lemma with silky trichomes, whitish and delicate on margins; base of plant with hispid trichomes (figure $5 \mathrm{~d}$ ) 18.8. P. urvillei

6. Upper glume and lower lemma glabrous or with short and discreet trichomes; base of plant glabrous, pubescent or with soft sparse trichomes 
7. Nodes glabrous; lower lemma with a hyaline portion at the center; sheath glabrous or with sparse trichomes or only on margins; spikelets 1.1-1.4 mm long, solitary, arranged in 2 series in the racemes 18.4. P. hyalinum

7. Nodes hirsute; lower lemma uniform, without a hyaline portion at the center; sheath pubescent; spikelets 1.8-2 $\mathrm{mm}$ long in pairs, arranged in 4 series in the racemes (figure 5e) 18.3. P. dasytrichum

18.1. Paspalum compressifolium Swallen, Phytologia 14(6): 381. 1967.

For figures, see Longhi-Wagner et al. (2001) or Zuloaga \& Morrone (2005).

Distribution: South America. In Brazil, it occurs in the Central-West, Southeast and South regions (LonghiWagner et al. 2001, Zuloaga \& Morrone 2005, Flora do Brasil 2020).

Habitat: Grassland with wet sandy soil.

Conservation: DD. Native.

Specimens examined: BRAZIL. ParanÁ: Tibagi, Parque Estadual do Guartelá, 22-X-1999, I.J.M. Takeda et al. (ICN122952 - additional material).

18.2. Paspalum cordatum Hack., Ark. Bot. 9(15): 5. 1910.

Figure 5a

Distribution: South America. In Brazil, it occurs in the Northeast, Central-West, Southeast and South regions (Renvoize 1988, Longhi-Wagner et al. 2001, Zuloaga \& Morrone 2005, Flora do Brasil 2020).

Habitat: Grassland with wet sandy soil.

Conservation: DD. Native.

Specimens examined: BRAZIL. Paraná: Tibagi, Parque Estadual do Guartelá, 26-III-2015, T. Souza et al. 50 (UNOP), 02-VI-2015, T. Souza et al. 52 (UNOP), 21-I-2016, T. Souza et al. 51 (UNOP).

18.3. Paspalum dasytrichum Dusén ex Swallen, Phytologia 14(6): 363. 1967.

Figure 5e

Distribution: endemic to Brazil, occurring in the Southeast and South regions (Renvoize 1988, LonghiWagner et al. 2001, Zuloaga \& Morrone 2005, Flora do Brasil 2020).

Habitat: Grassland with wet sandy soil.

Conservation: DD. Native.

Specimens examined: BRAZIL. Paraná: Tibagi, Parque Estadual do Guartelá, 04-XI-1994, M.E. Buim
(ICN191100 - additional material). BRASIL. PARANÁ: Tibagi, Parque Estadual do Guartelá, 26-X-2015, T. Souza et al. 53 (UNOP), 26-VIII-2016, T. Souza et al. 83 (UNOP).

18.4. Paspalum hyalinum Nees ex Trin., Gram. Panic.: 103. 1826.

For figures, see Longhi-Wagner et al. (2001) or Zuloaga \& Morrone (2005).

Distribution: South America. In Brazil, it occurs in the North, Northeast, Central-West, Southeast and South regions (Renvoize 1988, Longhi-Wagner et al. 2001, Zuloaga \& Morrone 2005, Flora do Brasil 2020).

Habitat: Grassland with drained sandy soil.

Conservation: DD. Native.

Specimens examined: BRAZIL. Paraná: Tibagi, Parque Estadual do Guartelá, 26-III-2015, T. Souza et al. 54 (UNOP).

18.5. Paspalum notatum Flüggé, Gram. Monogr., Paspalum: 106. 1810.

Figure $5 b$

Distribution: North, Central and South America. In Brazil, it occurs in the North, Northeast, Central-West, Southeast and South regions (Renvoize 1988, LonghiWagner et al. 2001, Zuloaga \& Morrone 2005, Flora do Brasil 2020).

Habitat: Grassland with drained sandy soil.

Conservation: DD. Native.

Specimens examined: BRAZIL. PARANÁ: Tibagi, Parque Estadual do Guartelá, 26-X-2015, T. Souza et al. 55, 56 (UNOP).

18.6. Paspalum polyphyllum Nees ex Trin., Gram. Panic.: 114. 1826.

Figure 5c

Distribution: South America. In Brazil, it occurs in the Northeast, Central-West, Southeast and South regions (Renvoize 1988, Longhi-Wagner et al. 2001, Zuloaga \& Morrone 2005, Flora do Brasil 2020). 


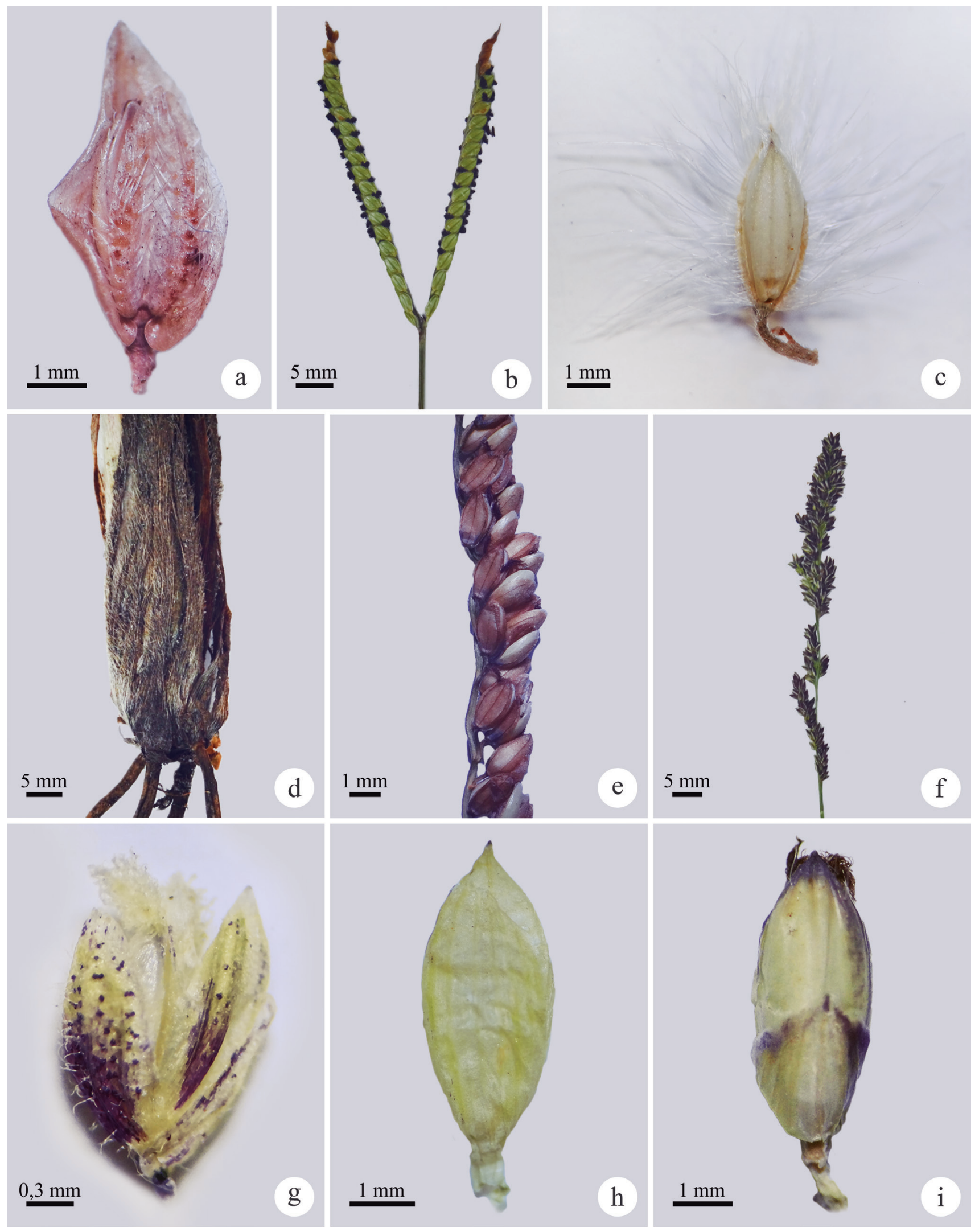

Figure 5. a. Paspalum cordatum, spikelet. b. P. notatum, inflorescence. c. P. polyphyllum, spikelet. d. P. urvillei, base of the plant. e. P. dasytrichum, detail of a fragment of the inflorescence branch. f. Steinchisma decipiens, inflorescence. g. Trichanthecium pseudisachne, spikelet. h. Urochloa humidicola, spikelet. i. U. brizantha, spikelet. 
Habitat: Grassland with wet and drained sandy soil and rock outcrops. Ruderal.

Conservation: DD. Native.

Specimens examined: BRAZIL. Paraná: Tibagi, Parque Estadual do Guartelá, 26-III-2015, T. Souza et al. 57, 58, 59 (UNOP), 02-VI-2015, T. Souza et al. 60, 61 (UNOP).

18.7. Paspalum rojasii Hack., Repert. Spec. Nov. Regni Veg. 7: 369. 1909.

For figures, see Longhi-Wagner et al. (2001).

Distribution: South America. In Brazil, it occurs in the Northeast, Central-West, Southeast and South regions (Longhi-Wagner et al. 2001, Flora do Brasil 2020).

Habitat: Grassland with drained sandy soil.

Conservation: DD. Native.

Specimens examined: BRAZIL. ParanÁ: Tibagi, Parque Estadual do Guartelá, 05-III-2004, M.R.B. do Carmo 793 (ICN - additional material).

18.8. Paspalum urvillei Steud., Syn. P1. Glumac. 1: 24. 1853.

Figure $5 \mathrm{~d}$

Distribution: North and South America. In Brazil, it occurs in the Northeast, Central-West, Southeast and South regions (Renvoize 1988, Longhi-Wagner et al. 2001, Zuloaga \& Morrone 2005, Flora do Brasil 2020).

Habitat: Grassland with wet sandy soil. Ruderal.

Conservation: DD. Native.

Specimens examined: BRAZIL. Paraná: Tibagi, Parque Estadual do Guartelá, 26-X-2015, T. Souza et al. 62 (UNOP).

19. Pharus P.Browne, Civ. Nat. Hist. Jamaica: 344. 1756.

19.1. Pharus lappulaceus Aubl., Hist. P1. Guiane 2: 859. 1775.

Figure 2a

Distribution: North and South America. In Brazil, it occurs in the North, Northeast, Central-West, Southeast and South regions (Longhi-Wagner et al. 2001, Flora do Brasil 2020).

Habitat: Edge of Mixed Ombrophilous Forest with drained sandy soil.
Conservation: DD. Native.

Specimens examined: BRAZIL. Paraná: Tibagi, Parque Estadual do Guartelá, 21-I-2016, T. Souza et al. 63 (UNOP).

20. Piptochaetium J.Presl, Reliq. Haenk. 1: 222. 1830.

20.1. Piptochaetium montevidense (Spreng.) Parodi, Revista Fac. Agron. Veterin. 7: 163. 1930.

For figures, see Zanin et al. (1992) or Longhi-Wagner et al. (2001).

Distribution: South America. In Brazil, it occurs in the Southeast and South regions (Renvoize 1988, Zanin et al. 1992, Longhi-Wagner et al. 2001, Flora do Brasil 2020).

Habitat: Grassland with drained sandy soil.

Conservation: DD. Native.

Specimens examined: BRAZIL. PARAnÁ: Tibagi, Parque Estadual do Guartelá, 26-VIII-2015, T. Souza et al. 64 (UNOP).

21. Pseudechinolaena Stapf, Fl. Trop. Afr. 9: 494. 1919.

21.1. Pseudechinolaena polystachya (Kunth) Stapf, Fl. Trop. Afr. 9: 495. 1919.

For figures, see Longhi-Wagner et al. (2001).

Distribution: Pantropical. In Brazil, it occurs in the North, Northeast, Central-West, Southeast and South regions (Renvoize 1988, Longhi-Wagner et al. 2001, Flora do Brasil 2020).

Habitat: Edge of Mixed Ombrophilous Forest with drained sandy soil.

Conservation: DD. Native.

Specimens examined: BRAZIL. Paraná: Tibagi, Parque Estadual do Guartelá, 21-I-2016, T. Souza et al. 65 (UNOP).

22. Rugoloa Zuloaga, P1. Syst. Evol. 300(10): 2164. 2014.

22.1. Rugoloa pilosa (Sw.) Zuloaga, Pl. Syst. Evol. 300(10): 2164. 2014.

For figures, see Guglieri \& Longhi-Wagner (2000) or Longhi-Wagner et al. (2001). 
Distribution: North, Central and South America. In Brazil, it occurs in the North, Northeast, Central-West, Southeast and South regions (Renvoize 1988, Guglieri \& Longhi-Wagner 2000, Longhi-Wagner et al. 2001, Flora do Brasil 2020).

Habitat: Edge of Mixed Ombrophilous Forest with drained sandy soil.

Conservation: DD. Native.

Specimens examined: BRAZIL. Paraná: Tibagi, Parque Estadual do Guartelá, 21-I-2016, T. Souza et al. 74 (UNOP).

23. Setaria P.Beauv., Ess. Agrostogr.: 51. 1812.

Key to the Setaria species of Parque Estadual do Guartelá

1. Basal sheaths laterally compressed, keeled; inflorescence speciform pendant or erect, with basal secondary branches inconspicuous; spikelets accompanied by 4-9 involucral bristles. 23.2. S. sphacelata

1. Basal sheaths not laterally compressed, cylindrical; inflorescence sub-speciform erect, with basal secondary branches conspicuous 5-18 mm long; spikelets accompanied by 1-3 involucral bristles (figure 3d) ... 23.1. S. scabrifolia

23.1. Setaria scabrifolia (Nees) Kunth, Révis. Gramin. 1: 40. 1833.

Figure 3d

Distribution: South America. In Brazil, it occurs in the Northeast, Southeast and South regions (Boldrini 1976, Renvoize 1988, Longhi-Wagner et al. 2001, Flora do Brasil 2020).

Habitat: Grassland with drained sandy soil.

Conservation: DD. Native.

Specimens examined: BRAZIL. Paraná: Tibagi, Parque Estadual do Guartelá, 26-III-2015, T. Souza et al. 66, 67 (UNOP), 2-VI-2015, T. Souza et al. 68, 69 (UNOP), 21-I-2016, T. Souza et al. 70 (UNOP).

23.2. Setaria sphacelata (Schumach.) Stapf \& C.E. Hubb. ex M.B. Moss, Kew Bull. 1929(6): 195. 1929.

For figures, see Longhi-Wagner et al. (2001).

Distribution: Tropical, Subtropical and temperate regions. In Brazil, it occurs in the North, Northeast, Central-West, Southeast and South regions (Longhi-
Wagner et al. 2001, Flora do Brasil 2020).

Habitat: Grassland with drained sandy soil.

Conservation: Exotic.

Specimens examined: BRAZIL. ParanÁ: Tibagi, Parque Estadual do Guartelá, 31-I-2005, M.R.B. do Carmo 1116 (ICN - additional material).

24. Sorghastrum Nash in Britton, Man. Fl. N. States: 71. 1901.

Key to the Sorghastrum specis of Parque Estadual do Guartelá

1. Panicle spiciform; spikelets sessile 7-10 mm long, stramineous to pale yellow, awn (45-)50-75 mm long, callus acute and pungent 2.5-3.5 mm long ......... 24.1. S. minarum

1. Panicle sub-open or open; spikelets sessile 4-6.0 mm long, dark brown, awn 10-26 mm long, callus obtuse and not pungent 0.2-0.6 mm long 24.2. S. scaberrimum

24.1. Sorghastrum minarum (Nees) Hitchc., Contr. U.S. Natl. Herb. 24: 501. 1927.

For figures, see Davila (1988), Flores \& Valls (1992) or Longhi-Wagner et al. (2001).

Distribution: South America. In Brazil, it occurs in the North, Northeast, Central-West, Southeast and South regions (Davila 1988, Renvoize 1988, Flores \& Valls 1992, Longhi-Wagner et al. 2001, Flora do Brasil 2020).

Habitat: Grassland with drained sandy soil.

Conservation: DD. Native.

Specimens examined: BRAZIL. PARANÁ: Tibagi, Parque Estadual do Guartelá, 11-II-2004, M.R.B. do Carmo 755 (ICN - additional material).

24.2. Sorghastrum scaberrimum (Nees) Herter, Revista Sudamer. Bot. 6: 136. 1940.

For figures, see Davila (1988) or Longhi-Wagner et al. (2001).

Distribution: endemic to Brazil, occurring in the Southeast and South regions (Davila 1988, LonghiWagner et al. 2001, Flora do Brasil 2020).

Habitat: Grassland with wet sandy soil and rock outcrops. 
Conservation: DD. Native.

Specimens examined: BRAZIL. Paraná: Tibagi, Parque Estadual do Guartelá, 4-III-2004, M.R.B. do Carmo 780 (ICN - additional material).

25. Sporobolus R.Br., Prodr. Fl. Nov. Holland.: 169. 1810.

25.1. Sporobolus indicus (L.) R.Br., Prodr. Fl. Nov. Holland.: 170. 1810.

Figure 2d

Distribution: North and South America. In Brazil, it occurs in the North, Northeast, Central-West, Southeast and South regions (Renvoize 1988, Boechat \& Longhi-Wagner 1995, Longhi-Wagner et al. 2001, Flora do Brasil 2020).

Habitat: Grassland with drained sandy soil. Ruderal. Conservation: DD. Native.

Specimens examined: BRAZIL. Paraná: Tibagi, Parque Estadual do Guartelá, 26-VIII-2015, T. Souza et al. 71 (UNOP).

26. Steinchisma Raf. in Ser. Bull. Bot. (Geneva) 1: 220. 1830.

Key to the Steinchisma species of Parque Estadual do Guartelá

1. Plants erect; inflorescence in panicle contracted; primary branches adpressed to the main axis (figure 5f); adaxial face of leaf blade with tuberculate trichomes, deciduous; spikelets 1.7-2.3 mm long arranged in all rachis directions 26.1. S. decipiens

1. Plants decumbent, less frequently erects; inflorescence in panicle lax to sub-contracted; primary branches diverging from main axis; abaxial and adaxial face of leafblade glabrous; spikelets 1-1.4 mm long facing the same side of rachis 26.2. S. laxum

26.1. Steinchisma decipiens (Nees ex Trin.) W.V. Br., Mem. Torrey Bot. Club 23(3): 20. 1977. Figure 5f

Distribution: South America. In Brazil, it occurs in the North, Northeast, Central-West, Southeast and South regions (Renvoize 1988, Longhi-Wagner et al. 2001, Flora do Brasil 2020).

Habitat: Grassland with wet sandy soil.
Conservation: DD. Native.

Specimens examined: BRAZIL. PARANÁ: Tibagi, Parque Estadual do Guartelá, 26-X-2015, T. Souza et al. 72 (UNOP).

26.2. Steinchisma laxum (Sw.) Zuloaga, Amer. J. Bot. 90(5): 817. 2003.

Figure $3 \mathrm{~g}$

Distribution: North, Central and South America. In Brazil, it occurs in the North, Northeast, Central-West, Southeast and South regions (Renvoize 1988, Guglieri \& Longhi-Wagner 2000, Longhi-Wagner et al. 2001, Flora do Brasil 2020).

Habitat: Grassland with wet sandy soil. Ruderal.

Conservation: DD. Native.

Specimens examined: BRAZIL. Paraná: Tibagi, Parque Estadual do Guartelá, 21-I-2016, T. Souza et al. 73 (UNOP).

27. Trachypogon Nees, Fl. Bras. Enum. P1. 2: 341. 1829.

27.1. Trachypogon spicatus (L.f.) Kuntze, Revis. Gen. P1. 2: 794. 1891.

Figure $2 \mathrm{~g}$

Distribution: Tropical Africa, North, Central and South America. In Brazil, it occurs in the North, Northeast, Central-West, Southeast and South regions (Renvoize 1988, Flora do Brasil 2020).

Habitat: Grassland with drained sandy soil.

Conservation: DD. Native.

Specimens examined: BRAZIL. Paraná: Tibagi, Parque Estadual do Guartelá, 02-VI-2015, T. Souza et al. 75 (UNOP), 21-I-2016, T. Souza et al. 76 (UNOP).

28. Trichanthecium Zuloaga \& Morrone, Syst. Bot. Monogr. 94: 13. 2011.

Key to the Trichanthecium species of Parque Estadual do Guartelá

1. Blades oval-lanceolate to lanceolate expanded at the base, subcordate to cordate; spikelets glabrous 28.1. T. cyanenscens

1. Blades linear to linear-lanceolate becoming narrower toward the base, not subcordate; spikelets pilose, rarely glabrous (Figure $5 \mathrm{~g}$ ) 28.2. T. pseudisachne 
28.1. Trichanthecium cyanescens (Nees ex Trin.) Zuloaga \& Morrone, Syst. Bot. Monogr. 94: 25. 2011.

For figures, see Zuloaga et al. (2011).

Distribution: Central and South America. In Brazil, it occurs in the North, Northeast, Central-West, Southeast and South regions (Zuloaga et al. 2011, Flora do Brasil 2020).

Habitat: Grassland with wet sandy soil.

Conservation: DD. Native.

Specimens examined: BRAZIL. Paraná: Tibagi, Parque Estadual do Guartelá, 26-X-2015, T. Souza et al. 28 (UNOP).

28.2. Trichanthecium pseudisachne (Mez) Zuloaga

\& Morrone, Syst. Bot. Monogr. 94: 69. 2011.

Figure $5 \mathrm{~g}$

Distribution: endemic to Brazil, occurring in the Northeast, Central-West, Southeast and South regions (Longhi-Wagner et al. 2001, Zuloaga et al. 2011, Flora do Brasil 2020).

Habitat: Grassland with wet sandy soil.

Conservation: DD. Native.

Specimens examined: BRAZIL. Paraná: Tibagi, Parque Estadual do Guartelá, 21-I-2016, T. Souza et al. 78 (UNOP).

29. Urochloa P.Beauv., Ess. Agrostogr.: 52. 1812.

Key to the Urochloa species of Parque Estadual do Guartelá

1. Sheaths and blades glabrous; lower glume $3 / 4$ or equal the spikelet length (figure $5 \mathrm{~h}$ ) 29.3. U. humidicola

1. Sheaths and blades pilose or ciliate; lower glume reaching up to half the spikelet length (figure 5i)

2. Rachis $0.5-0.8 \mathrm{~mm}$ width; spikelets 1-rowed on the rachis, rare 2-rowed at the base of raceme 29.1. U. brizantha

2. Rachis 1-1.8 mm width; spikelets 2-rowed on the rachis 29.2. U. decumbens

29.1. Urochloa brizantha (Hochst. ex A. Rich.) R.D. Webster, Austral. Paniceae: 233. 1987.

Figure 5i
Distribution: Native to Tropical Africa and cultivated in most continents. In Brazil, it occurs in the North, Northeast, Central-West, Southeast and South regions (Sendulsky 1978, Renvoize 1988, Longhi-Wagner et al. 2001, Flora do Brasil 2020).

Habitat: Grassland with drained sandy soil. Ruderal. Conservation: Exotic.

Specimens examined: BRAZIL. Paraná: Tibagi, Parque Estadual do Guartelá, 26-VIII-2015, T. Souza et al. 80 (UNOP).

29.2. Urochloa decumbens (Stapf) R.D.Webster, Austral. Paniceae: 234. 1987.

Figure $3 f$

Distribution: Tropical Africa, introduced as forage in Tropical America. In Brazil, it occurs in the North, Northeast, Central-West, Southeast and South regions (Sendulsky 1978, Longhi-Wagner et al. 2001, Flora do Brasil 2020).

Habitat: Grassland with drained sandy soil. Ruderal. Conservation: Exotic.

Specimens examined: BRAZIL. ParanÁ: Tibagi, Parque Estadual do Guartelá, 26-VIII-2015, T. Souza et al. 81 (UNOP).

29.3. Urochloa humidicola (Rendle) Morrone \& Zuloaga, Darwiniana 31: 80. 1992.

Figure $5 \mathrm{~h}$

Distribution: Tropical Africa, introduced as forage in Tropical America. In Brazil, it occurs in the North, Northeast, Central-West, Southeast and South regions (Sendulsky 1978, Longhi-Wagner et al. 2001, Flora do Brasil 2020).

Habitat: Grassland with drained sandy soil. Ruderal. Conservation: Exotic.

Specimens examined: BRAZIL. ParanÁ: Tibagi, Parque Estadual do Guartelá, 26-VIII-2016, T. Souza et al. 82 (UNOP).

\section{Acknowledgments}

We are grateful to the Universidade Estadual do Oeste do Paraná and to the Universidade Federal de Santa Catarina for the infrastructure provided. To the curators and technicians of the herbaria FLOR, ICN, MBM and UNOP. We also thank the Parque Estadual do Guartelá team and the Instituto Ambiental do Paraná for the collecting permits and the infrastructure provided. 


\section{Literature cited}

Aguiar, T.H. \& Vieira, A.O.S. 2011. Florística do Parque Estadual do Cerrado de Jaguariaíva - Paraná: atualização da lista de espécies. In: O.T.B. Carpanezzi \& J.B. Campos (orgs.). Coletânea de Pesquisas: Parques Estaduais de Vila Velha, Cerrado e Guartelá. Instituto Ambiental do Paraná, Curitiba, pp. 263-272.

Alvares, C.A., Stape, J.L., Sentelhas, P.C., Gonçalves, J.L.M. \& Sparovek, G. 2014. Köppen's climate classification map for Brazil. Meteorologische Zeitschrift 22: 711-728.

Boechat, S.C. 2005. O gênero Ichnanthus (Poaceae Panicoideae - Paniceae) no Brasil. Iheringia, Série Botânica 60: 189-248.

Boechat, S.C. \& Longhi-Wagner, H.M. 1995. O gênero Sporobolus (Poaceae: Chloridoideae) no Brasil. Acta botanica brasílica 9: 17-73.

Boechat, S.C. \& Longhi-Wagner, H.M. 2001. O gênero Eragrostis (Poaceae) no Brasil. Iheringia, Série Botânica 55: 23-169.

Boldrini, I.I. 1976. Gramineas do genero Setaria Beauv. no Rio Grande do Sul. Anuário Técnico do Instituto de Pesquisas Zootécnicas Francisco Osorio 3: 331-422.

Boldrini, I.I., Longhi-Wagner H.M. \& Castro Boechat, S. 2008. Morfologia e Taxonomia de Gramíneas: SulRio-Grandenses. 2 ed. Universidade Federal do Rio Grande Sul, Porto Alegre.

Bridson, D. \& Forman, L. 2004. The Herbarium Handbook. The Royal Botanic Garden, Kew.

Carmo, M.R.B. 2006. Caracterização fitofisionômica do Parque Estadual do Guartelá, município de Tibagi, estado do Paraná. Tese de Doutorado, Universidade Estudal Paulista "Julio de Mesquita Filho", Rio Claro.

Carmo, M.R.B. \& Assis, M.A. 2012. Caracterização florística e estrutural das florestas naturalmente fragmentadas no Parque Estadual do Guartelá, município de Tibagi, estado do Paraná. Acta Botanica Brasilica 26: 133-145.

Carmo, M.R.B., Andrade, A.L.P., Santos, G.A.S.D. \& Assis, M.A. 2012. Análise estrutural em relictos de Cerrado no Parque Estadual do Guartelá, município de Tibagi, estado do Paraná, Brasil. Ciência Florestal 22: 505-517.

Centro Nacional de Conservação da Flora (CNCFlora). 2016. Available in http://cncflora.jbrj.gov.br/portal/ (access in 14-III-2017).

Clayton, W.D. 1972. Studies in the Gramineae: XXIX. Kew Bulletin 27: 447-450.

Davila, P.D. 1988. Systematic revision of the genus Sorghastrum (Poaceae: Andropogoneae). Doctoral thesis, Iowa State University, Iowa.
Ferreira, A.P. \& Maranho, L.T. 2011. Avaliação da sucessão ecológica da Estepe Gramíneo - Lenhosa pouco alterada após fogo controlado e roçada no Parque Estadual Vila Velha, PR, Brasil. In: O.T.B. Carpanezzi \& J.B. Campos (orgs.). Coletânea de Pesquisas: Parques Estaduais de Vila Velha, Cerrado e Guartelá. Instituto Ambiental do Paraná, Curitiba, pp. 36-45.

Filgueiras, T.S. 2003. Eriochrysis P. Beauv. In: F.O. Zuloaga, O. Morrone, G. Davidse, T.S. Filgueiras, P.M. Peterson, R.J. Soreng, \& E.J. Judziewicz (eds.). Catalogue of New World Grasses (Poaceae): III. Subfamilies Panicoideae, Aristidoideae, Arundinoideae and Danthonioideae. Contributions from the United States National Herbarium, Washington, v. 46, pp. 1-662.

Filgueiras, T.S., Brochado, A.L., Nogueira, P.E. \& Guala II, G. F. 1994. Caminhamento - um método expedito para levantamentos florísticos qualitativos. Cadernos de Geociências 2: 39-43.

Flora do Brasil 2020 (em construção). 2017. Jardim Botânico do Rio de Janeiro. Available in http:// floradobrasil.jbrj.gov.br/ (access in 10-X-2017).

Flores, A.I.P. \& Valls, J.F.M. 1992. O gênero Sorghastrum Nash (Gramineae: Andropogoneae) no Rio Grande do Sul, Brasil. Iheringia 42: 25-54.

Freitas, D.B., Miyamoto, S.N.A. \& Carmo, M.R.B. 2011. Análise estrutural de um Campo Limpo em regeneração após duas décadas de uso agrícola no Parque Estadual de Vila Velha, Ponta Grossa, PR. In: O.T.B. Carpanezzi \& J.B. Campos (orgs.). Coletânea de Pesquisas: Parques Estaduais de Vila Velha, Cerrado e Guartelá. Instituto Ambiental do Paraná, Curitiba, pp. 62-66.

Guglieri, A. \& Longhi-Wagner, H.M. 2000. Gramineae Paniceae: Gênero Panicum L. Boletim do Instituto de Biociências 59: 1-163.

IAP (Instituto Ambiental do Paraná. 2002. Plano de manejo do Parque Estadual do Guartelá. Instituto Ambiental do Paraná, Curitiba.

Kaehler, M. 2014. Poaceae. In: M. Kaehler, R. Goldenberg, P.H.L. Evangelista, O.S. Ribas, A.O.S. Vieira \& G.G. Hatschbach (eds.). Plantas Vasculares do Paraná. Universidade Federal do Paraná, Curitiba, pp. 103-106.

Kawakita, K., Rodrigues, R.S. \& Filgueiras, T.S. 2016. Poaceae em uma planície de inundação no Brasil: listagem florística e novas ocorrências. Hoehnea 43: 203-216.

Labiak, P.H. 2014. Aspectos fitogeográficos do Paraná. In: M. Kaehler, R. Goldenberg, P.H.L. Evangelista, O.S. Ribas, A.O.S. Vieira \& G.G. Hatschbach (eds.). Plantas vasculares do Paraná. Universidade Federal do Paraná, Curitiba, pp. 7-22.

Longhi-Wagner, H.M. 1999. O gênero Aristida (Poaceae) no Brasil. Boletim do Instituto de Botânica 12: 113-179. 
Longhi-Wagner, H.M., Bittrich, V., Wanderley, M.G.L. \& Shepherd, G.J. 2001. Poaceae. In: M.G.L. Wanderley, G.J. Shepherd \& A.M. Giulietti (orgs.). Flora Fanerogâmica do Estado de São Paulo. FAPESP \& HUCITEC, São Paulo, v. 1, pp. 1-317.

Lorenzi, H. 2014. Manual de identificação e controle de plantas daninhas - plantio direto e concencional. $7 \mathrm{ed}$. Instituto Plantarum, São Paulo.

Maack, R. 2012. Geografia física do estado do Paraná. 4 ed. Universidade Estadual de Ponta Grossa, Ponta Grossa.

Maia, F.R. \& Goldenberg, R. 2014. Melastomataceae from the "Parque Estadual do Guartelá", Tibagi, Paraná, Brazil: Species list and field guide. Journal of species lists and distribution 10: 1316-1323.

Michelon, C. \& Labiak, P.H. 2013. Samambaias e Licófitas do Parque Estadual do Guartelá, PR, Brasil. Hoehnea 40: 191-204.

Oliveira, M.B. \& Maranho, L.T. 2011. Efeitos do fogo controlado e do roçado sobre a sucessão ecológica da Estepe Gramineo-Lenhosa no Parque Estadual de Vila Velha, PR, Brasil, em área com avanço de vassoura (Bacharis spp.). In: O.T.B. Carpanezzi \& J.B. Campos (orgs.). Coletânea de Pesquisas: Parques Estaduais de Vila Velha, Cerrado e Guartelá. Instituto Ambiental do Paraná, Curitiba, pp. 46-55.

Oliveira, E., Putrique, M., Ribas, D.C. \& Panizon, M. 2011. Monitoramento de Sus scrofa (Mammalia, Suidae) no Parque Estadual de Vila Velha, Paraná, Brasil. In: O.T.B. Carpanezzi \& J.B. Campos (orgs.). Coletânea de Pesquisas: Parques Estaduais de Vila Velha, Cerrado e Guartelá. Instituto Ambiental do Paraná, Curitiba, pp. 85-93.

Renvoize, S.A. 1988. Hatschbach's Paraná grasses. The Royal Botanic Gardens, Kew.

Santos, A.M.P.V. \& Boechat, S.C. 1989. Gramineae: Tribo Danthonieae. Boletim do Instituto de Biociências 44: 1-57.

Sendulsky, T. 1978. Brachiaria: taxonomy of cultivated and native species in Brazil. Hoehnea 7: 99-139.

Sendulsky, T. \& Soderstrom, T. R. 1984. Revision of the South American genus Otachyrium (Poaceae: Panicoideae). Smithsonian contributions to botany 57: 1-24.

Silva, A.R., Andrade, A.L.P., Velazco, S.E., Galvão, F. \& Carmo, M.R.B. 2016. Florística e fitossociologia em três diferentes fitofisionomias campestres no Sul do Brasil. Hoehnea 43: 325-347.
Soreng, R.J., Peterson, P.M., Romaschenko, K., Davidse, G., Zuloaga, F.O., Judziewicz, E.J., Filgueiras, T.S., Davis, J.I. \& Morrone, O. 2015. A worldwide phylogenetic classification of the Poaceae (Gramineae). Journal of Systematics and Evolution 53: 117-137.

The IUCN Red List of Threatened Species (IUCN). 2016. Available in http://www.iucnredlist.org/ (access in 14-III-2017).

Thiers, B. [continuously updated]. 2017. Index Herbariorum: a global directory of public herbaria and associated staff. New York Botanical Garden's Virtual herbarium. Available in http://sweetgum.nybg.org/ih/ (access in 01-II-2017).

Vasconcellos, G.C. \& Rocha, M.R.L. 2011. A importância dos Parques Estaduais de Vila Velha, Guartelá e Cerrado na produção e divulgação de conhecimento científico. In: O.T.B. Carpanezzi \& J.B. Campos (orgs.). Coletânea de Pesquisas: Parques Estaduais de Vila Velha, Cerrado e Guartelá. Instituto Ambiental do Paraná, Curitiba, pp. 7-8.

Veloso, H.P., Filho, A.L.R.R. \& Lima, J.C.A. 1991. Classificação da vegetação Brasileira, adaptada a um sistema universal. Instituto Brasileiro de Geografia e Estatística, Rio de janeiro.

World Checklist of Selected Plant Families (WCSP). 2016. Available in http://apps.kew.org/wcsp/ (access in 15-X-2016).

Welker, C.A.D. 2011. Os gêneros Eriochrysis P. Beauv., Imperata Cirillo, Saccharum L. e Schizachyrium Nees (Poaceae - Andropogoneae) no Rio Grande do Sul, Brasil. Dissetação de Mestrado, Universidade Federal do Rio Grande do Sul, Porto Alegre.

Welker, C.A.D. \& Longhi-Wagner, H.M. 2012. The genera Eriochrysis P. Beauv., Imperata Cirillo and Saccharum L. (Poaceae - Andropogoneae - Saccharinae) in the state of Rio Grande do Sul, Brazil. Brazilian Journal of Botany 35: 87-105.

Zanin, A. \& Longhi-Wagner, H.M. 2011. Revisão de Andropogon (Poaceae - Andropogoneae) para o Brasil. Rodriguésia 62: 171-202.

Zanin, A., Mujica-Salles, J. \& Longhi-Wagner, H.M. 1992. Gramineae: Tribo Stipeae. Boletim do Instituto de Biociências 51: 1-174.

Zuloaga, F. O. \& Morrone, O. 2005. Revisión de las especies de Paspalum para América del Sur austral (Argentina, Bolivia, sur del Brasil, Chile, Paraguay y Uruguay). Monographs in systematic botany from the Missouri Botanical Garden, Missouri.

Zuloaga, F.O., Morrone, O. \& Scataglini, M.A. 2011. Monograph of Trichanthecium (Poaceae, Paniceae). Systematic Botany Monographs 94: 1-98. 